\title{
Absurdy codzienności w optyce komizmu u kronikarzy polskich XIX i XX wieku (na przykładzie Bolesława Prusa i Antoniego Słonimskiego)
}

Agata Grabowska-Kuniczuk 


\section{Absurdy codzienności w optyce komizmu u kronikarzy polskich XIX i XX wieku (na przykładzie Bolesława Prusa i Antoniego Słonimskiego)}

On [absurd] jest w myśleniu, w pojmowaniu świata, albo, jak czasem chcielibyśmy, w samym świecie - jako jego alternatywa, odbicie wykrzywione tak, że dać nam może poczucie zabawy, mocy i szczęścia.

Jerzy Bralczyk ${ }^{1}$

Humor to widzenie świata na osi absurdu i niedorzeczności.

ks. Tadeusz Dejczer ${ }^{2}$

Rzetelny absurd uwarunkowany jest bezlitosnym kryterium śmieszności.

Antoni Słonimski ${ }^{3}$

$\mathrm{B}$ ohaterami tego artykułu będą dwaj felietoniści i pojęcie absurdu, którego istnienia w szczególny sposób doświadczali.

Dwaj kronikarze, dwie epoki, dwie osobowości - Bolesław Prus ${ }^{4}$ i Antoni Słonimski ${ }^{5}$. Spotkali się przypadkiem, przelotnie w przedpokoju domu ojca Antoniego,

${ }^{1}$ J. Bralczyk, Wstęp do: A. Słonimski, J. Tuwim, Woparach absurdu, Warszawa 2008, s. 6.

2 T. Dejczer, „Cnota” humoru w shuzbie wiary, w: idem, Rozważania o wierze: z zagadnień teologii duchowości, Częstochowa 1994, s. 105.

${ }^{3}$ A. Słonimski, J. Tuwim, $W$ oparach absurdu, op. cit., s. 8.

${ }^{4}$ O Prusie-kronikarzu pisali m. in.: Barbara Bobrowska (Bolestaw Prus - mistrz pozytywistycznej kroniki, Białystok 1999), Stanisław Fita (Wstęp do: B. Prus Kroniki. Wybór, t. 1-2, Warszawa 1987), Józef Bachórz (Wstęp do: B. Prus, Kroniki. Wybór, opr. J. Bachórz, Wrocław 1994, BN I 285; przedr. Wrocław 2005).

5 O Antonim Słonimskim i jego kronikarskiej twórczości przeczytać można m. in. w pracach: Piotra Stasińskiego, Marka Pytasza, Doroty Maciei, Romana Lotha, Rafała Habielskiego, Piotra Sitkiewicza. 
doktora Stanisława Słonimskiego — podobnego w sposobie bycia i działania Prusowi społecznika-humorysty. Świadectwem zetknięcia się mistrza-kronikarza i przyszłego, kreującego się na jego następcę, równie dobrze wykonującego później swą profesję felietonisty (i jednocześnie poety) są wspomnienia tego ostatniego. Przywołują jednak obraz tylko jedynej, krótkiej i „dość jednostronnej” - jak twierdzi Antoni Słonimskisyn - „rozmowy” z Prusem, który przyszedł z książką do Słonimskiego-ojca. Sprowadzała się ona do jednej kwestii wypowiedzianej przez autora Lalki: „Niech kawaler odda to panu doktorowi”.

Można byłoby rzec, że felietoniści minęli się w „przedpokoju historii”, obaj podejmujący w różnych czasach trud pisania do gazet po to, aby zarabiać na utrzymanie (nie mogąc przeto oddzielić życia od literatury), a także po to, aby walczyć piórem o lepsze jutro społeczeństwa, którego cząstkę stanowili.

Dopelnieniem spotkania Prusa i Słonimskiego, kronikarzy, którzy — jak pisze Piotr Sitkiewicz -

należeli do różnych pokoleń, ale połączyły ich miłość do Warszawy, wspólne ideały oraz przede wszystkim wieloletnie „użeranie się z głupotą i złością ludzką" w cotygodniowych kronikach ${ }^{7}$

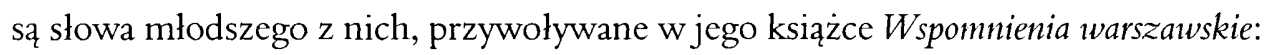

Prus bywał u nas w domu. $\mathrm{Z}$ mglistego o nim wspomnienia zostaly mi tylko w pamięci jego czarne okulary.

Właśnie w szkłach okularów, bez których obydwaj twórcy nie mogli się obejść w życiu powszednim, odbijały się obrazy codzienności z jej trudnymi sprawami, niczym we wklęsłych lub wypuklych zwierciadłach („co pomniejszało wielkość przedmiotów odbijanych [...] bądź [...] przeciwnie, powiększało ją") stawianych przed czytelnikami kronik dwóch następujących po sobie epok. Analiza i interpretacja faktów miała doprowadzić właśnie do takich zabiegów powiększania rzeczy małych, ledwo dostrzegalnych, a jednak, według kronikarzy, godnych uwagi, albo też pomniejszania czy raczej poniżania aspektów, które na forum publicznym wyraźnie przerysowywano.

\footnotetext{
${ }^{6}$ A. Stonimski, Alfabet wspomnień, Warszawa 1998, s. 196.

7 P. Sitkiewicz, Antoni Stonimski jako felietonista, praca magisterska napisana pod kierunkiem prof. dr hab. Małgorzaty Czermińskiej, Uniwersytet Gdański, Gdańsk 2004, IBL Masz. 6018 (praca wyróżniona w X edycji Konkursu prac magisterskich im. Jana Józefa Lipskiego).

${ }^{8}$ A. Słonimski, Wspomnienia warszawskie, Warszawa 1987, s. 9.

${ }^{9}$ Mieczysław Wallis pisze: „Powierzchnia polerowana [zwierciadła greckiego] była bądź z lekka wklęsła, co pomniejszało wielkość przedmiotów odbijanych, bądź - najczęściej - z lekka wypukła, co, przeciwnie, powiększało ją" (idem, Dzieje zuierciadła i jego rola $w$ różnych dziedzinach kultury, Warszawa 1973, s. 15).
} 


\section{Przyczyny i skutki oglądania obrazów codzienności w ,krzywym zwierciadle” społeczno-obyczajowej satyry}

W kronikach „krzywe zwierciadło” satyry rozbija się na tysiące, miliony kawałków, w których odbijają się wady społeczeństwa, po to, aby w szczególny sposób ukazać rzeczywistość, obnażając absurdy jej istnienia.

Właśnie do granic absurdu posunięte są niektóre przykłady społecznych zachowań, codziennych zdarzeń, na których jak cień kładzie się ludzka głupota, brak logiki w myśleniu i postępowaniu.

Kronikarze - Prus i Słonimski podjęli się misji uświadamiania istnienia problemów życia społecznego, „dokładnego ich kopiowania” ${ }^{10}$ i konieczności stawiania im czoła. Dlatego we właściwy sobie sposób piętnowali i zwalczali absurdy codzienności. Porwani niebezpiecznym nurtem „rzeki Bzdury” musieli konsekwentnie dążyć do opanowania sytuacji - spokojnie przypominając o istotnych kwestiach, podsuwając propozycje ich rozwiązania lub stwarzając całkowicie wyimaginowaną, bezsensowną wizję konsekwencji trwania w bierności. Pomocne okazało się w tym zjawisko absurdu, wytwarzające szczególny rodzaj dystansu do przejawów zagmatwanej codzienności, który mógł zostać posunięty aż do całkowitego „odcięcia się” od samoistnie i niekontrolowanie mnożących się nonsensów, skupiając się na produkowaniu własnych, paradoksalnie, będących reakcją na te juz istniejące.

Te świadome „wyprawy w krainę bzdury i absurdu” umożliwiały łatwiejsze rozpoznawanie nonsensów, tkwiących nawet głęboko w rzeczywistości i zmieniających ją czasem nie do poznania, a także ich wyławianie, wytykanie i piętnowanie (przez wprowadzenie elementów fantastycznych, jak w grotesce, czy przejaskrawień charakterystycznych dla karykatury). Taki sposób dyskredytowania przeciwnika, właśnie przez jego ośmieszenie, nie tylko go „obezwładnia”, ale jasno określa role — „zwycięzcy” i „pokonanego”. Zdemaskowany absurd pozostawia już tylko możliwość przyznania się do porażki.

\footnotetext{
${ }^{10}$ W kronice z „Kuriera Warszawskiego” z 3 kwietnia 1877 roku Prus pisze: „przekonałem się, że najznakomitszą humorystyką jest samo życie i że dla skromnego oficjalisty z "Kuriera» celem marzeń powinno być tylko: dokładne kopiowanie życia. $Z$ tego powodu w tym, co powiem niżej, znajdziecie tylko fotografie rzeczy widzianych, ani zaś słówka przesady lub własnego konceptu" (cyt. za.: B. Prus, Wojtusie. Szkice i drobiazgi, opr. L. Włodek, w: idem, Pisma, t. 2, Warszawa [1918], s. 48). Felietonista zdaje się kokietować swoich czytelników, udając, że w jego felietonach czytelnik nie znajdzie niczego oprócz czystej dawki życia w życiu. Ale wcielanie się w rolę fotografa rzeczywistości to także akt kreacji, bowiem sam proces postrzegania realnych rzeczy czy zjawisk i ich opisywania bądź opowiadania o nich jest już przecież próbą interpretacji (swoistym dysponowaniem własnym konceptem względem przedmiotu obserwacji).
} 


\section{Sposoby rozumienia i funkcjonowania absurdu (jako szczególnej postaci komizmu ${ }^{11}$ )}

Czym jest zatem absurd, a także jakie było jego rozumienie? Słowo „absurd” pochodzi od łacińskiego słowa absurdus, co tłumaczy się jako 'niedorzeczność', a oznacza, jak podaje Stownik wyrazów obcych:

powiedzenie, sąd, przypuszczenie niedorzeczne lub samo sobie przeczące, lub też z całą oczywistością fałszywe ${ }^{12}$.

Zjawisko to nazywane jest także purnonsensem, w znaczeniu:

odmiana dowcipu, w której komiczny efekt rodzi się z jawnej niedorzeczności - ze skojarzenia pojęć lub obrazów zaskakująco nielogicznego, pozbawionego motywacji, uderzającego w poczucie zdrowego rozsądku, bezinteresownie absurdalnego ${ }^{13}$.

Niewątpliwie jego używanie daje człowiekowi - posiadającemu naturalny dar humoru i umiejętność jego wykorzystywania - siłę przekonywania, potęgę w działaniu, a tym samym swoiste „panowanie” nad innymi. Jego istnienie można najlepiej pokazać na przykładzie dzieci, które niejako od urodzenia „bzdurzą"14, a w ich szeregach panuje „najfantastyczniejszy kult bredni” ${ }^{15}$ — jak twierdzi przyjaciel Sło-

11 Od czasów starożytnych przetrwało przeświadczenie, że patos i śmiech mogą istnieć naprzemiennie, a komizm to odwrotna strona tragedii, silnie z nią związany. Dziś uważa się, że komizm (istota śmiesznego) to zjawisko dotyczące zarówno przedmiotu, jak i podmiotu, zestawionych ze sobą na zasadzie kontrastu. Wyzwolona w ten sposób śmieszność i/bądź komiczność, czyli cecha „łamiąca nastawienie podmiotu", zmierza do osiągnięcia celu, jakim jest przeżycie komizmu. Wyrażaniu istoty śmieszności mogą towarzyszyć m. in.: kontrast wewnętrzny, sprzeczność, opaczność, niezgodność (terminy poboczne określające przedmiot zjawiska komizmu) oraz wyższość, degradacja, świadomość sprzeczności, dystans (terminy poboczne właściwe podmiotowi zjawiska komizmu) i inne techniki wywoływania przeżyć komizmu, na które mają bezpośredni wpływ np. charaktery postaci podmiotu. Sytuacja zaistnienia zjawiska komizmu nie może być dokładnie określona, gdyż dotyczy zbyt wielu czynników, z których nadrzędnym jest subiektywizm odczuć.

Jedną z technik wywoływania przeżyć komizmu lub określenia aktów psychicznych towarzyszących jego doznaniu może być „opaczność” lub „niedorzeczność”. Mogą one posłużyć jako cechy wyrażające istotę absurdu. (Zob. A. Główczewski, O głównych terminach teorii komizmu, „Acta Universitatis Nicolai Copernici” z. 276, 1994, s. 127-153). Według koncepcji Wolfganga Schmidta-Hiddiga istnieje osiem kategorii komizmu, wśród których jako siódmy autor wymienia „nonsens” (obok humoru, dowcipu, ironii, satyry, sarkazmu, żartu i cynizmu) - cyt. za: K. Żygulski, Wspólnota śmiechu, Warszawa 1976, s. 5 .

${ }^{12}$ Hasło absurd, w: Stownik uyrazów obcych, red. Z. Rysiewicz, Warszawa 1958, s. 25.

${ }^{13}$ Hasło pure nonsense, w: Słownik terminów literackich, red. J. Sławiński, Wrocław 1998, s. 456.

${ }^{14}$ A. Słonimski, J. Tuwim, $W$ oparach absurdu, op. cit., s. 17.

${ }^{15}$ Ibidem, s. 16. 
nimskiego, Julian Tuwim (współautor absurdalnego materiału przygotowywanego na potrzeby wydania książki $W$ oparach absurdu). O zjawisku wszechobecności absurdów w życiu dziecka, które nie obejdzie się bez „bajki, złudy, wymysłu i czarodziejstwa"16, kierując się stale fantastycznymi wyobrażeniami, pisze Słonimski we Wspomnieniach warszawskich:

Wiem, jak dzieci wrażliwe są na purnonsensy, [...] kiedyś gdy mieszkałem $\mathrm{w}$ pokoju odnajętym przy rodzinie, co rano rozmawiałem w ten sposób z młodszym synem pani domu, Tomciem. Było tam dwóch chłopaków znanych na całej ulicy $z$ hałaśliwości. Gdy ktoś pytał się starszego Jasia, czy nie przeszkadzają mi w pracy, Jaś odpowiedział: „Pan Słonimski nie pracuje: on albo śpi, albo pisze". Młodszy mial przywilej przynoszenia mi co rano do lóżka gazety. Utarło się zwyczajowo, że witałem Tomcia jakimś mniej lub bardziej zawiłym powiedzeniem. Starszy czekał pod drzwiami i pytal: „Co powiedział?” „Powiedzial: Oto i pan Tomasz we własnej postaci”. Kiedyś powiedziałem coś za trudnego: „Nie narodzone jeszcze pokolenia uwielbiać będą ten żarcik pana Tomasza, który w nowej sukience zjawił się w ostatni dzień starego roku”. „Co powiedział?” — spytał Jaś, ale pan Tomcio nie umiał powtórzyć i rozplakal się ${ }^{17}$.

Jakie są reakcje na rozpoznany absurd? Kiedy czytelnik zdaje sobie sprawę, że ma do czynienia z nonsensem, często zawiesza głos, jakby chciał się upewnić w swym rozpoznaniu. Trwa wymowne milczenie, które kojarzy się z otwarciem ust lub/i rozłożeniem rąk w geście bezradności. Takiemu zachowaniu często towarzyszy chwilowe rozdrażnienie, nerwowość, czasem wzburzenie, a następnie ogólna wesołość, która świadczy o nabraniu dystansu do zdemaskowanej rzeczywistej wartości danej wypowiedzi bądź sytuacji. Nagłe doświadczenie absurdu pozostawia wrażenie bezradności, sprawia, że ludzie stają się niczym dzieci poruszające się we mgle. Być może stąd właśnie wziął się tytul książki Tưwima i Słonimskiego - W oparach absurdu.

Charakterystycznymi cechami absurdu są: kompletność (czystość), „dziwność istnienia"18, fakt, że pozostaje on w sprzeczności z logiką, łatwość w rozpoznaniu, ponieważ stanowi alternatywę rzeczywistości, tworząc swoisty „świat na opak”. Antoni Slonimski dodaje ponadto:

Rzetelny absurd uwarunkowany jest bezlitosnym kryterium śmieszności ${ }^{19}$.

\footnotetext{
${ }^{16}$ Słowa Juliana Tuwima z książki $W$ oparach absurdu (ibidem, s. 17).

${ }^{17}$ A. Stonimski, Wspomnienia warszawskie, op. cit., s. 9.

${ }^{18}$ A. Słonimski, J. Tuwim, Woparach absurdu, op. cit., s. 8 (Są to słowa zaczerpnięte ze wstępu do książki napisanego przez Antoniego Słonimskiego).

${ }^{19}$ Ibidem.
} 
W historii literatury, chcąc oddać istotę absurdu, używano także innych określeń. Były wśród nich: „cuda”, „mistyfikacje”, „androny” (termin ten przetrwał w zwrocie „pleść androny”), „dziwy” (jak w wyrażeniu „dziwy abo absurda”20 użytym w tytułach kilku utworów ze zbioru Jakuba Teodora Trembeckiego Wirydarz poetycki), bowiem, jeśli wierzyć słowom Juliana Tuwima z eseju $W$ oparach absurdu zamieszczonego w jego książce Pegaz dęba:

Takich upodobań ludu do kpin ze zdrowego rozsądku i zamierzonej antylogiki przytoczyć można mnóstwo. Lubowała się w nich szlachta, lubowali się obywatele i mieszczanie $[\ldots]^{21}$

\section{Antoni Słonimski - kolekcjoner bzdur}

Zdarza się, że opisywana rzeczywistość przestaje już śmieszyć, a nawet przeciwnie - zasmuca, niebezpiecznie zmniejszając dystans komentatora do opisywanych wypadków. Trzeba temu przeciwdziałać i koniecznie znaleźć jak najlepsze wyjście $z$ tej trudnej sytuacji. Dlatego Słonimski „porwal się” na nowatorskie rozwiązanie — stwarzanie nowego sensu w bezsensie „piętrowej” bzdury. Z pomocą przyszła mu umiejętność prowadzenia $z$ odbiorcą swoistej gry, w której się odnajdywal, a nawet doskonale się nią bawił. Było to przekształcanie w komentarzu zdarzeń w taki sposób, aby doprowadzić je do granic absurdu. Takie „wywracanie na lewą stronę” lub, jak kto woli, „odwracanie do góry nogami” przejawów codzienności nie było mu zresztą obce, ponieważ wcześniej (w latach 1920-1936) tworzył już z Tuwimem podobne teksty satyryczne, wykorzystując do tego celu utwory literackie czy też anonse, porady, przepisy kulinarne bądź zagadki. Od dawna bawił się więc Słonimski kolekcjonowaniem bzdur.

Kronikarz, będąc człowiekiem o dużej odwadze cywilnej, nieprzebierającym w słowach, jeśli chodziło o obronę wartości moralnych czy też jego własnych prawd i przekonań, często kategorycznie przeciwstawial się głupocie, której „niewyczerpaną dziedzinę" stanowila dlań prasa codzienna ${ }^{22}$ :

Terenem walk była rzeka Bzdura wraz z jej dopływami z lewej i prawej strony. Rzeka ta nie umiejscowiona na żadnej mapie, rozlewa się bardzo szeroko po całym kraju i powoduje liczne powodzie. Starałem się tu nie-

\footnotetext{
20 J. T. Trembecki, Wirydarz poetycki, wyd. A. Brückner, t. 1, Lwów 1910, s. 26.

${ }^{21} \mathrm{~J}$. Tuwim, $W$ oparach absurdu, w: idem, Pegaz dęba, Warszawa 2008, s. 373.

22 Odwołuję się do fragmentu, w którym Słonimski pisze: „Prawdziwych, naturalnej wielkości zdarzeń szukać można tylko jeszcze w jednej niewyczerpanej dziedzinie głupoty ludzkiej — prasie codziennej" (idem, Moje walki nad Bzdurq, Warszawa 1932, s. 18).
} 
raz podać rękę ludziom tonącym w szarych falach rzeki Bzdury i to ratownictwo usprawiedliwia wiele moich okrucieństw wojennych ${ }^{23}$.

Wszelkim społecznym, ludzkim pomyłkom mówił: „nie!” i po prostu je wyśmiewał:

Rozbije się czasem, nad naszymi głowami, wielka bania z głupotą. Nazywa się to niż barometryczny albo depresja nad Bałtykiem. Od rana pada na głowę kapuśniaczek idiotyzmu, kretynizm leje się jak z cebra i w końcu obrywa się cała chmura głupstw ${ }^{24}$.

Największym przejawem głupoty ludzkiej, a także uwikłania się człowieka w pułapkę absurdu, jest dla Słonimskiego dążenie do wojny ${ }^{25}$ :

Choroba wojny jest już znana, lasecznik tego zarazka jeszcze nie jest zgładzony, - ale już wiemy gdzie go szukać i jak zwalczać. Wiemy, że sublimatem odkażającym są właśnie słowa. Dlatego, gdy pisarz dotyka tej sprawy, mówi o rzeczach uznanych za najwyższe zło grożące cywilizacji — obowiązywać go winna sumienność najwyższa ${ }^{26}$.

Rozwój tej choroby ukrywa się czasem pod pozorem całkowicie akceptowalnych zachowań społecznych:

Przypadkowe rekordy w głupim fachu lekkoatletycznym nie są żadnym dowodem tężyzny narodu, jak to chce nam wmówić prasa warszawska. [...] Pod przykrywką wychowania fizycznego odbywa się w całej Europie wyszkolenie wojskowe. Sport staje się coraz bardziej narzędziem militaryzmu. Dziwne jest tylko, iz sztaby generalne pragną mieć mięso armatnie w jak najlepszym gatunku. Po co trenować i sportować ciała, które mają być i tak zmasakrowane? ${ }^{27}$

Fragment o budowie opery ukazuje kolejny absurd codzienności, potwierdzając niejako starą (jeszcze antyczną) prawdę „nie ma chleba — ale są igrzyska”:

trudno nie wspomnieć o budowaniu nowej opery w Warszawie. [...] Jednej nam mało? Stoi śliczny gmach, architektonicznie jeden z najład-

${ }^{23} \mathrm{Ibidem}, \mathrm{s}$. 6. Jest to fragment cytowany również przez Romana Lotha w przedmowie do: A. Słonimski, Kroniki tygodnioue 1927-1931, Warszawa 2001, s. 8.

24 Cyt za: D. Macieja, Tygodnie Stonimskiego, Warszawa 2000, s. 59.

${ }_{25}$ „W sprawie pacyfizmu był Słonimski natomiast nieubłagany [...] wykorzystywał każdą okazję, każdy cudzy tekst, który by mu pozwolił wątek ten po swojemu rozwinąć” (P. Stasiński, Poetyka i pragmatyka felietonu, Wrocław 1982, s. 101-102).

${ }_{26}$ A. Słonimski, Moje walki nad Bzdurq, op. cit., s. 43.

${ }^{27}$ Ibidem, s. 89. 
niejszych w Warszawie, i świeci pustkami. Czego jak czego, ale opery mamy przecież więcej niż potrzeba, bo gdyby gmach Teatru Wielkiego nie mógł pomieścić widzów, gdyby choć raz na rok ktoś u nas nową operę napisal, można by powiedzieć: trudno, ta stara machina jeszcze dyszy, trzeba jej dać więcej powietrza. W epoce radia, transmisyj międzynarodowych - muzyka innymi drogami dostaje się do szerokich mas. Wybudujcie dosyć szkół, żeby ludzi nauczyć czytać, dosyć szpitali, żeby nie zdychali pod płotem, dosyć domów, żeby mieli gdzie spać, zmniejszcie frekwencję cmentarzy i więzień, a frekwencja w operze na pewno się podniesie ${ }^{28}$.

Można by mnożyć podobne przykłady absurdów jakby „zatopionych” w ludzkiej rzeczywistości, śledząc felietony Słonimskiego, który walczył z nimi zapamiętale nie tylko kronikarskim piórem. Godził w nie przede wszystkim bezlitosnym ostrzem satyry, kreując w ten sposób (wspólnie z Julianem Tuwimem) nowy świat literackich nonsensów. Prawdziwym bowiem antidotum na „wytropiony” absurd rzeczywistości jest wyśmiać go, wymyślając inny, większy.

\section{Z kronik Prusa, fotografa „rzeczy widzianych”}

Powszechnie znane poglądy Prusa na temat humoru i dowcipu opierają się w dużym stopniu na zjawisku absurdu:

Zabawne zaś produkcje umysłowe podzielić można na dwie klasy [...] Są nimi: $1^{\circ}$ dowcip, który jest utworem fantazji, $2^{\circ}$ humor, który wynika z obserwacji. [...]

Dowcip najgłębszy jest taką kombinacją pojęć, w której za pozorną niedorzecznością kryje się trafne spostrzeżenie [wyróżn. - A. G.-K.].[...]

Bardzo wiele może być gatunków dowcipu: każdy z nich jednak jest przede wszystkim produktem twórczej fantazji ${ }^{29}$.

\footnotetext{
28 Ibidem, s. 65. Podobny fragment, świadczący o dostrzeżonym przez pisarza braku wyczucia czasu i sytuacji u reformatorów i opiekunów kultury znaleźć można w jednej z kronik Prusa, gdzie felietonista pisze o budowaniu pomnika Adama Mickiewicza w Krakowie: „I w jakim celu stawiać mamy pomnik jakiemuś belferzynie z kowieńskiej szkoły średniej? Jaka korzyść z tego wyrośnie? Rozumialbym pomnik Sienkiewicza: na cokole figura pięknego mężczyzny; kobiety w odmiennym stanie zapatrywałyby się i na świat przychodziliby dorodniejsi Polacy" (cyt za: A. Grzymała-Siedlecki, Niepospolici ludzie $w$ dniu suoim powszednim, Kraków 1961, s. 14).

${ }^{29}$ B. Prus, Słówko o krytyce pozytywnej. Poemat realistyczny w 6 pieśniach, w: idem, Pisma, red. Z. Szweykowski, t. 29: Studia literackie, artystyczne i polemiki, Warszawa 1950, s. 174-175.
} 
Owa fantazja, a także determinacja popchnęły Prusa do poszukiwań obiektów tak przez niego pożądanej obserwacji, które można sklasyfikować jako oczywiste przykłady „stwarzanych” przez życie absurdów codzienności. Podkreślają one jego pisarską umiejętność obnażania wszelkich przejawów głupoty, której wykorzystywanie miało wyrażać niezgodę na zastaną sytuację i wyzwalać żywioł ośmieszającej negacji. Działo się tak w przypadku zdemaskowania przez kronikarza niedorzeczności, niedostrzeganych przez społeczeństwo, czy zaistnienia przejawów sprzeciwu wobec bezsensu utartych stosunków społecznych, które czas, jak się wydaje, powinien już dawno zweryfikować.

W kronice z „Kuriera Warszawskiego” z 22 lipca 1875 roku Prus pisał:

Niańki z dziećmi mają prawo wchodzić do ogrodu, zwyczajne sługi nie. Dama nosząca perukę na głowie wchodzi tam bez pytania; chlopiec zaś fryzjerski, niosący tęż samą perukę w pudle, nie wchodzi, mimo to, że się pyta ${ }^{30}$.

W innym miejscu tego felietonu stwierdzał również, że

byłoby bardziej pożądane dokładniejsze niż dotychczas określenie powierzchowności osób nie zasługujących na to, aby miały prawo oddychać drogocennym kurzem Saskiego Ogrodu ${ }^{31}$.

Prus poświęca fragmenty kronik między innymi problemom dnia powszedniego, podsuwając ich rozwiązania. Mówi o potrzebie brukowania ulic, budowania kanalizacji i toalet miejskich („Znamy kamienice, w których są marmurowe schody, kolumny, posąi, weneckie okna i malowidła na ścianach. Ale «miejsc...» nie ma wcale!”32) oraz o innych podobnych sprawach, które według niego miałyby sens i służyły dobru publicznemu.

Małe niedorzeczności życia codziennego są wydobywane przez Prusa-kronikarza z takim zapamiętaniem niczym tony uprzykrzającej życie katarynki:

Można słyszeć na podwórkach rozdzierające dźwięki katarynek, ale to nie żebranina, tylko artyzm ${ }^{33}$.

Obsesyjnie powracający motyw dokuczliwej katarynki być może ma związek z niezwykle wyczulonym słuchem pisarza, który rozwinął się u niego wskutek cho-

\footnotetext{
30 „Kurier Warszawski” 1875 nr 159-160 (22-23 lipca), cyt. za wyd.: B. Prus, Kroniki, opr. Z. Szweykowski, t. 2, Warszawa 1953, s. 136.

${ }^{31}$ Ibidem.

32 B. Prus, Wojtusie. Szkice i drobiazgi, op. cit., s. 102.

${ }^{33}$ Ibidem, s. 170.
} 
roby oczu ${ }^{34}$. I choć narratorowi Prusowskich Kronik przeszkadzały także inne hałasy - wyśpiewywane przez sąsiada godzinki, wrzaski dobiegające z podwórka, fałszywe dźwięki orkiestry itp. — istnienie katarynki mogło mieć dla pisarza-felietonisty zgoła niewspólmiernie wielkie znaczenie, a instrument ten mógł stać się dlań wręcz symbolem drobnych absurdów.

Kolejnym przykładem codziennych niedorzeczności może być także złe traktowanie sług:

Z rzecza zaś, która nazywa się tutejszą stuga, postępuje całkiem inaczej. Zamiast palisandrowej szafy dają jej najgorszy kąt $\mathrm{w}$ domu; nie tylko nie chronią jej od szkody, ale nawet sami plamią. Zamiast szacunku — gardzą nią, nie chcą, ażeby wychodziła na spacer lub na zabawę (co przeciė̇ odpowiada wietrzeniu garderoby) i wymagają od niej tysiąca najrozmaitszych użytków, zapominając, że przecież nikt nie ma pretensji do surduta, ażeby służył mu jako surdut i jako płaszcz i jako kamizelka ${ }^{35}$.

Wskutek tak bezpardonowego postępowania wytworzyły się najsmutniejsze stosunki między „panami” i „sługami”.

Jak wynika z przytoczonych fragmentów, Kroniki Prusa stawiają w nowym świetle liczne palące problemy i stanowią źródło poważnych argumentów w wielu istotnych sprawach społecznych. Pozornie ukryte w nich absurdy codzienności wyzwalają w Prusie-kronikarzu ekspresję satyryczną podobną do gorzkiego, wręcz nerwowego śmiechu, którym zdają się być podszyte niektóre części jego felietonów.

\section{Absurdy codzienności odbite w szkłach felietonistów-satyry- ków - podsumowanie}

Rezultaty swych wnikliwych obserwacji ${ }^{36}$ obaj felietoniści opatrywali cennymi komentarzami, w których zwracali uwagę na szereg ważnych społeczno-obyczajowych

34 Powodem tej choroby była poważna rana głowy odniesiona przez 16-letniego wówczas Olesia w bitwie pod Białką w czasie powstania styczniowego. Z czasem Prus widział coraz gorzej, a słuch jego stawał się bardziej wyczulony. Podobnie jak bohater Katarynki, pisarz także nienawidził hałaśliwych dźwięków tych urządzeń.

${ }^{35}$ B. Prus, Wojtusie. Szkice i drobiazgi, op. cit., s. 256.

${ }^{36}$ Wnikliwa obserwacja życia znaczy tyle, co, jak pisał Prus: „obserwować, i jeszcze raz obserwować oto zadanie pisarza!" (Z. Rabska, Prus i Alkar, cyt. za: Wspomnienia o Bolestawie Prusie, zebr. i opr. S. Fita, Warszawa 1962, s. 232). Był to jego sposób na poznawanie codzienności i zmagających się z nią ludzi. Dla nich pisał z odcinka na odcinek kroniki, w których — jak pisze Stanisław Fita, przyblizając charakterystykę felietonu i jego twórców - „Felietonista zdaje się swobodnie rozmawiać z czytelnikiem, tak jak rozmawia się przy stoliku w kawiarni, przerzucając się swobodnie z tematu na temat, chętnie operując dygresjami, zmieniając ton i nastrój wypowiedzi [...]" (S. Fita, Wstęp, do: B. Prus, Kroniki. Wybór, op. cit., t. 1, s. 6). 
kwestii. A wszystko to podane było w jak najatrakcyjniejszej, sprawdzonej lub przeciwnie - nowatorskiej formie (u Prusa „podlane lekkim werniksem blagi”, u Słonimskiego często całkowicie przetworzone) - po to, aby praca kronikarzy została doceniona, by ich felietony były czytane, a także, a może przede wszystkim, żeby ich kronikarska twórczość przysporzyła im popularności.

W swych kronikach — zarówno Prus, jak i Słonimski - ukazali codzienność XIX i XX wieku, odbitą pod różnymi kątami w „zniekształcającym zwierciadle” absurdu. Pasja jego odkrywania, piętnowania, a nawet artystycznego kreowania jego literackich postaci towarzyszyła dwóm kronikarzom w ich codziennych pisarskich zmaganiach o tak uniwersalne wartości życia, jak dobro, prawda i piękno. Opowieść o Platońskiej triadzie - o dobru, prawdzie i pięknie, bądź jej odwróconej, niechcianej i niepopularnej postaci - o złu, kłamstwie i brzydocie stała się im bardzo bliska. Jej idea stale powracala w swych wielokrotnych, przetworzonych wizerunkach, odbita w zwierciadłach okularów felietonistów-satyryków. 